\title{
Editorial: Resetting Power in Global Food Governance: The UN Food Systems Summit
}

\author{
Maywa Montenegro de Wit ${ }^{1} \cdot$ Matt Canfield ${ }^{2} \cdot$ Alastair les $^{3} \cdot$ Molly Anderson $^{4} \cdot$ Nora McKeon $^{5} \cdot$ Shalmali Guttal $^{6}$. \\ Barbara Gemmill-Herren ${ }^{7}$ Jessica Duncan ${ }^{8} \cdot$ Jan Douwe van der Ploeg ${ }^{9,10} \cdot$ Stefano Prato $^{11}$
}

Published online: 3 November 2021

(c) Society for International Development 2021

The October 2019 announcement by UN Secretary General António Guterres of a UN Food Systems Summit (UNFSS) acknowledged the dire conditions of the global food system. ${ }^{1}$ Today there is widespread consensus among a growing number of scientists, civil society organizations, and governments that the global food system cannot be sustained in its current configuration-economically, ecologically, or socially. Food insecurity and malnutrition now affect almost 3 billion people, and food systems are major contributors to climate change, biodiversity loss, and deforestation. Past food crises generated a series of high-level multilateral summits, each of which introduced changes in the global institutional arrangements dedicated to the elusive goal of ending hunger. Yet when the UN Secretary General announced the UNFSS, it was immediately clear that this meeting would differ from past summits in both form and substance. Although the UN Secretary General regularly organizes summits as a way to place key issues under the

Maywa Montenegro de Wit, Matt Canfield, Alastair Iles, Molly Anderson, Nora McKeon, Shalmali Guttal, Stefano Prato: These authors comprise the editorial collective for this Special Issue in Development.

Maywa Montenegro de Wit, Matt Canfield: These two authors are co-lead editors of the Special Issue.

Stefano Prato

stefanop@sidint.org

1 Department of Environmental Studies, University of California, Santa Cruz, CA, USA

2 Van Vollenhoven Institute for Law, Governance, and Society, Leiden Law School, Leiden, The Netherlands

3 Environmental Science, Policy, and Management, University of California, Berkeley, USA

4 Middlebury College, Middlebury, VT, USA

5 International University College of Turin and Roma Tre, Rome, Italy spotlight of national leaders, in this case, this power was used to jumpstart a process that potentially reconfigures global food governance, bypassing existing intergovernmental institutions with both the mandate and legitimacy to address these issues.

As its name implies, the Food Systems Summit marked a distinct pivot away from past global food summits through its focus on food systems. A conceptual approach to food production and provisioning that is much broader than the narrow focus on agricultural productivity, the food systems lens has been advanced and advocated for by many academic and social movement communities dedicated

\footnotetext{
1 In this editorial, we use the term 'food system' to encompass the entire range of actors and their interlinked activities involved in the production, aggregation, processing, distribution, consumption and disposal of food products that originate from agriculture, forestry, or fisheries, and parts of the broader economic, societal and natural environments in which they are embedded (FAO 2014). We use 'the global food system' to refer to the current hegemonic order. This food system, which McMichael (2009) refers to as the 'corporate food regime', emerged out of the global economic shocks of the 1970 s and 1980s ushering in the current period of neoliberal capitalist expansion. It is characterized by unprecedented market power of monopoly agrifood corporations and finance capital, globalized ani-
}

6 Focus on the Global South, Bangkok, Thailand

7 Prescott College, Prescott, AZ, USA

8 Rural Sociology Group, Wageningen University, Wageningen, The Netherlands

9 Wageningen University, Wageningen, The Netherlands

10 China Agricultural University, Beijing, China

11 Society for International Development, Rome, Italy 
to agroecology-including in the deliberations of the UN Committee on World Food Security (CFS). This approach recognizes the multiple functions of food systems, as well as their reciprocal impacts on economic, social, and ecological systems (Francis et al. 2003; HLPE 2020). Complex and diverse cross-sectoral links, rural-urban ties, and local-global connectivities of food production, exchange, and consumption make the value of a food systems lens undeniable. The Summit's systems aperture was, therefore, a welcome departure from the singular production focus that has long dominated global food narratives. Yet in expanding the frame of reference of the Summit to food systems, the UNFSS also attempted to transform the structure through which global food governance has been organized.

The adoption of food systems language by UNFSS has intensified frictions in a territory of conflict in which multiple parties are seeking to define food systems and thereby their governance. For example, the UNFSS adopted its scientific advisory group's mechanistic model of food systems (von Braun et al. 2021: Fig. 1); this 'integrated approach' expanded the sectoral scope of UNFSS interventions and widened their spheres of influence without recognizing power relations inherent to the dominant food system-inequities entangling race, class, gender, and more-and thus, without offering any real prospects for their reorganization (Clapp et al. this issue). The UNFSS food systems model, moreover, remained hidebound to the imperative of human control over nature; innovations almost ineluctably served up more efficient ways of transforming the Earth into cheap resources to enable accumulation. By contrast, 'food systems', for many Indigenous peoples, agroecologists, and peasant farmers, encompass a plurality of interpretations at odds with this anthropocentric and extractivist view. Among them are understandings that food systems are (or should be), non-hierarchical, regenerative, redistributive,

Footnote 1 (Continued)

mal protein chains, strong links between food and fuel economies, liberalized global trade in food, increasingly concentrated land ownership, a shrinking natural resource base, and growing opposition from food movements worldwide. By contrast, we use 'food systems' to mean the full multiplicity of food systems globally, from African, Asian, and Latin American rural peasant systems to European periurban agriculture systems to middle scale farming across the US Corn Belt (Anderson 2015). These food systems are tremendously diverse in their markets, production methods, geographies, and cultures. They often feature short supply chains, control of production and knowledge by farmers and local communities, and territorial markets embedded in local food cultures. We note that use of the singular 'global food system' can be used to eclipse and undermine the diversity of local food systems around the world. However, as has been the case with the UNFSS, a discourse of 'food systems' (in the plural) has also worked to treat all systems as coequally responsible for climate change, food insecurity, and other crises driven specifically by the corporate food regime and to flatten the power asymmetries between 'local food systems' and the larger global food order. and governed according to reciprocal rights and relations (Wittman 2009; Marya and Patel 2021).

The leadership selected by the Secretary General also clearly aligned the UNFSS with corporate and philanthropic interests that have long sought to promote market-oriented and technologically-driven approaches to food and agricultural systems. Instead of the United Nations' customary multilateral format, the leadership of the UNFSS organized the Summit as an 'inclusive' multi-stakeholder summit in which philanthropies, transnational corporations, and civil society were invited to participate on equal footing alongside international organizations and states. Though in principle, bringing voices beyond nation-states to the table is a laudable goal, in practice, 'stakeholderism' has long been part of attempts by the World Trade Organization and the World Bank to kneecap the public sector and then declare multilateralism ineffective, suggesting a governance vacuum that the private sector should fill (McMichael this issue). More recently, an ensemble including the World Economic Forum (WEF), philanthropies such as the Bill \& Melinda Gates Foundation, the Rockefeller Foundation, and EAT, market-friendly NGOs like the World Wildlife Fund, and corporations including Unilever, Nestlé, Tyson, and Bayer has continued to encourage the elaboration of multi-stakeholder platforms in food systems (Chandrasekaran et al. 2021). In contrast, the reform of the UN Committee on World Food Security triggered by the 2007-2008 food price crisis established a strong precedent for what could be called 'inclusive multilateralism' in which civil society and social movements are full participants, but decisionmaking is reserved for governments, who hence can be held accountable (McKeon this issue).

For civil society organizations and social movements, multi-stakeholderism raises profound concerns about the impossibility of 'equal footing' in a space of deeply unequal power relations. After the Summit was announced in 2019 , civil society organizations, academics, and human rights experts began studying the UNFSS process and calling out the corporate capture of UN institutions the Summit presaged as well as its lack of attention to human rights, accountability, and transparency (Canfield et al. 2021; Vidal 2021). In the ensuing two years, farmers and scientists globally boycotted the Summit and launched counter-mobilizations as it became evident that UNFSS was much more than an ambitious meeting. It was an ongoing process, poised to significantly reset power relations in global food security governance.

This issue of Development examines the politics of the UN Food Systems Summit and what it augurs for future global food governance. It examines the discourses and practices through which powerful actors are seeking to reframe food system governance, the shifting institutional 
arrangements that are emerging from the Summit, how a particular framing of science and technology is being wielded to justify specific paths of food system transformation, and what this means for control over the multiplicity of food systems globally. At a time when the global pandemic has exposed the precarities of the dominant model of industrial food production and neoliberal free trade, powerful actors are doubling down on their efforts to both coopt agroecology and to promote technological fixes that further enhance corporate consolidation and control over food systems (Clapp 2018; Fairbairn 2020). As a result, peasants, small-scale food producers, and food chain workers worldwide face new threats to their land, livelihoods, and knowledge, while consumers such as the urban poor face rising food insecurity and malnutrition. This Special Issue therefore examines the emerging terrain of struggles for more just and equitable food systems in a post-pandemic world.

\section{Setting the Scene}

The UN Food Systems Summit aimed to identify solutions and advance action to make progress on the Sustainable Development Goals. In so doing, it gave considerable attention to major food system problems, including hunger, loss of biodiversity, and the degradation of nature. These problems are indisputable.

However, as the contributions to this collection make clear, the solutions put forward by the UNFSS to address these problems are predominantly new extensions of old approaches, cloaked in rhetoric of 'innovation'. Since the proposed solutions are silent on the underlying drivers of the aforementioned crises, they were never likely to address the root causes of food insecurity: systemic inequality, concentrated power, and governance that works for corporations and elites rather than to support workers and ecological integrity. Indeed, 'game-changing solutions' coming out of the UNFSS are very likely to reinforce and potentially worsen existing problems. Innumerable examples exist of large-scale agricultural investment schemes that were touted as 'transformative' yet which instead delivered ecological and social harm, from the Southern Agricultural Growth Corridor (SAGCOT) of Tanzania (Twomey et al. 2015) to commercial shrimp operations in Bangladesh (Paprocki and Cons 2014), among many others. Even the organization led by the Special Envoy of the Summit, the Alliance for a Green Revolution in Africa (AGRA), has failed to meet its own stated goals; recent evidence suggests that AGRA has created new problems for farmers by pushing them into debt (Mkindi et al. 2020).

The authors in this Special Issue analyze the UN Food Systems Summit and consider alternatives to its constrained visions of food system transformation. In various ways, all contributions address a theme that is central to food systems governance, but which was intentionally evaded by the Summit's leadership: power. Articles in the Upfront section analyze the UNFSS within the context of shifting political, economic, and institutional arrangements of power, while articles in the Thematic Section attend to specific aspects of power. Articles in the Dialogue Section and Local/Global Encounters articulate place-specific and grounded analyses of power struggles as they are experienced first-hand.

For example, several authors in the Special Issue attend to the issue of corporate power, which remains a key driver of contemporary inequalities within food systems but was unaddressed by the Summit (McMichael this issue; Clapp et al. this issue). This is particularly the case in the Summit's approach to food security and nutrition, which ratified market-oriented, proprietary, and technology-driven approaches (Coutinho et al. this issue). Others attend to the way power was expressed through epistemic struggles over the colonial worldviews and visions of science embedded within the UNFSS (Montenegro de Wit and Iles this issue). Still others trace how the Summit evaded the legal structures through which power is structured by global food governance, such as intergovernmental decision-making entailing accountability (McKeon; Canfield et al.), trade law (Fakhri this issue) and human rights frameworks that clearly identify the duties and obligations of states (Guttal this issue). Throughout the articles, a key theme that emerges is the Summit's failures to address transformative solutions rooted in commons-based food systems (Kuljay et al. this issue), collective care (Van Dyck and Arora this issue), and corporate accountability (Dorado et al. this issue).

Of particular concern, agroecology was initially ignored and only included later under strong pressure from some participants. But it was rolled into the mix of 'Solution Clusters' offered by the UNFSS in a way that reduced it to a technical innovation strategy and bundled it together with other approaches with which it is clearly incompatible, including precision farming, biotechnology, artificial intelligence, and other investor-friendly solutions. This strategy of suppressing conflicting values and approaches through selective incorporation into dominant models reflects the wider method of the Summit. As in the case of agroecology, civil society organizations were selectively invited to participate in the Summit with the hopes that they would legitimize the UNFSS's claim to be a 'People's Summit'.

In this editorial article, we briefly analyze the underlying logic of Summit solutions, contrast it with agroecological principles, and demonstrate how an 'all the tools in the toolbox' argument is incoherent and undermines agroecological and food sovereign solutions. 


\section{Inventing Scarcities and Gaps that Don't Exist}

Going beyond narrow 'boost yield' claims of industrial agriculture, the UNFSS takes on the challenge of sustainability in food systems, alongside diversity, equity, and more. As a result, the Summit showcased complex and often contradictory trends, in which the global finance community was working on action tracks to 'mobilize private capital', while claims were made to 'elevate gender equality', 'support youth empowerment', and 'ensure human rights' (UNFSS 2021a). In terms of agriculture, the actor networks involved in outlining UNFSS food system solutions point to an ongoing 'inter-corporate' tension (Fakhri this issue), with some actors vying to move away from industrial approaches and towards less toxic 'Sustainable Intensification' strategies, while other actors work to stabilize existing agro-industrial technologies and infrastructures. Regardless, Sustainable Intensification principally serves a reformist agenda, touting improved resource efficiency and a smaller health and environmental footprint, while doing little to address inequitable power relations at the root of ecological sustainability and food insecurity. The dovetailing of industrial and Sustainable Intensification into 'new Green Revolution' approaches has bolstered corporate sector and philanthropic alliances at the UNFSS that are now seeking fresh legitimacy with appeals to ecological friendliness and social inclusivity. Despite this veneer of transformation, the dominant discourse of the UNFSS process has reproduced many old and undying tropes of modernist thinking, including assumptions of 'scarcity' —of food, knowledge, and development itself. These presumed scarcities give rise to a proliferation of gaps: 'knowledge gaps', 'technology gaps', 'evidence gaps', 'investment gaps', and 'policy gaps'. In this view, the role of public policy and public resources are primarily to facilitate private investment. In this view, a small set of academic and policy experts first frame the problems and judge which ideas match the variety of gaps they've argued must be filled.

The real gap, however, was that UNFSS 'solutions' continually failed to recognize the reality of small-scale, peasant, and Indigenous food production practices around the world. Such practices exist in spite of, not because of, mainstream neoliberal 'development' agendas. UN publications document that approximately 5 billion people on the planet are involved in diverse mixed production systems (far more than in 'modern' intensive food production systems) (UNEP 2016; Pengue et al. 2018). Even though industrial and globalized agriculture is seen as 'feeding the world', a comprehensive analysis has estimated that small and medium sized farms provide food to an estimated $2 / 3$ of the world's population, produce $51-77 \%$ of all food and nutrients, and show greater production in diverse landscapes (Herrero et al. 2017). This is the fundamental basis of the global food system; yet the rights, agency, and expertise of those who nourish most of the global population were not the foundation of the UNFSS discourse- and this is inexcusable.

The UNFSS approach was underwritten, above all, by the interests of powerful economic players. The WEF signed a strategic partnership agreement with the UN prior to the announcement of the UNFSS and has developed an explicit agenda to 'reset' global governance in the mold of 'stakeholder capitalism'. The UNFSS leader, Dr. Agnes Kalibata, President of the Alliance for a Green Revolution in Africa (AGRA), also reflected this private-sector driven vision of food systems transformation. AGRA has engaged in extensive policy advocacy and grantmaking to expand markets for corporate agro-inputs through multistakeholder and public-private partnerships. 'Naturepositive production' - which later morphed into 'Naturebased solutions'- became a new label put forward without articulation of fundamental principles nor documentation of successful applications of the actions proposed. Reference to the term can be traced to WEF reports from 2020 (WEF 2020), advocating for major shifts in thinking about the value of nature and for new, highly profitable business models enabled by Fourth Industrial Revolution technologies. Nature-positive production belongs to a family of related concepts that have been proposed to counter agroecology (climate-smart, precision farming, nutrition sensitive), which the High-Level Panel of Experts (HLPE) of the UN Committee on World Food Security identified as part of the Sustainable Intensification paradigm (HLPE 2019).

The Sustainable Intensification family of approaches contributes primarily to yield and stability but doesn't address social, cultural and political dimensions of transitions to sustainability, including power dynamics and governance (Loos et al. 2014; HLPE 2019). Although the UNFSS tried hard to avoid such associations, given the baggage of critical analysis, nature-positive production is old wine in new bottles. Like 'climate-smart agriculture,' which was once promoted as an alternative to agroecology (Newell and Taylor 2018), 'nature-positive production' is promoted as a climate change adaptation and mitigation strategy, without recognizing highly differentiated responsibilities for the climate crisis. As such, it is poised to push smallholders across the Global South either out of agriculture altogether or into adopting 'climate-smart' farming and 'digitalization'- - to solve problems that industrial food systems and consumption patterns in the North have caused or exacerbated.

What is the more effective approach? It is rooted in the practice and values of millions and generations of smallscale producers worldwide. It has many layers: It starts with considering the historical and ongoing role of colonialism, global capitalism, and corporate concentration in creating an unequal distribution of power and productive 
resources. It recognizes crises and conflicts that generate lack of access and instability-even when production is plentiful. It acknowledges that territorially-embedded markets, access to water and sanitation, agricultural income, women's education, and changes in gender relations are the most relevant pathways for improving food security and nutrition at the household level (Carletto et al. 2013; Smith and Haddad 2015). It grapples with the historical and ongoing violence of land dispossession enacted by capitalist agriculture and centers the expertise and agency of Indigenous peoples, peasants, women, and smallholder communities worldwide who are at the forefront of agroecological innovation today. Solutions that fail to address these issues and to promote food sovereignty-the ability of people to determine their own food systems-will fail to advance equitable and sustainable food systems for all (Nyéléni Declaration 2007; Sampson et al. 2021).

\section{The Case for Agroecology: Solutions from the Ground, Backed by Evidence}

Turning to small-scale, peasant, and Indigenous agriculture, we find that solutions are already underway. According to the HLPE (2019): 'Agroecological practices harness, maintain and enhance biological and ecological processes in agricultural production, in order to reduce the use of purchased inputs that include fossil fuels and agrochemicals and to create more diverse, resilient and productive agroecosystems'. Substantial evidence shows that the adoption of agroecology can lead to improvements in food security and nutrition (Carletto et al. 2013; Herforth and Harris 2014; Bezner Kerr et al. 2021). In addition, farms that are more agroecologically advanced exhibit advantages including: higher on-farm biodiversity; healthier soils; similar revenues to conventional systems but fewer expenditures on inputs, resulting in better net incomes; greater connectivity with natural landscapes; more diverse diets; greater self-sufficiency; and better linkages to local markets (Kremen and Miles 2012; Siliprandi 2021).

Agroecological approaches explicitly aim at transforming food and agriculture systems by addressing the root causes of problems with holistic and long-term strategies (FAO 2018) that consider the complexity of farming systems within their social, economic, and ecological contexts (Petersen and Arbenz 2018). In contrast to 'silver-bullet' solutions, agroecology relies on universal-yet-adaptable principles, recognizing that agroecological systems vary based on their local conditions. Agroecological approaches are also not 'new': they have a long history of innovation, as they are grounded in Indigenous and farmer-based practices and a 'dialogue of knowledges' (diálogo de saberes) that puts Western science into a role of mutual learning with social movements and traditional ecological knowledge keepers (Martínez-Torres and Rosset 2014; Pimbert et al. 2021). Practitioners of agroecology worldwide, in their various roles, communities, and geographies, recognize that knowledge is not something to be 'owned' or filled as a gap. It is collectively held, created in relation to living landscapes, and rooted in multiple valid ways of knowing and being in the world.

Documents that emerged from the UNFSS process referred to agroecology as an important innovation. Yet they ignore the fundamental understanding, also elaborated in the HLPE report, that innovation for sustainable food systems requires: (i) inclusive and participatory forms of innovation governance; (ii) information and knowledge co-production and sharing among communities and networks; and (iii) responsible innovation that steers innovation towards social issues (HLPE 2019). Without these, as has happened too often in the past, food security and nutrition cannot be achieved by the communities that need it the most. It is essential that agroecological principles are not used selectively to bolster certain 'innovations', but applied holistically.

In the 2015 Nyéléni Declaration of the International Forum for Agroecology, social movements from around the world affirmed a 'common understanding of agroecology as a key element in the construction of Food Sovereignty' (Nyéléni 2015). Social movements that are practicing agroecology and food sovereignty should be the ones to lead the development of both. More than 800 organizations and individuals have signed a letter calling for the 13 indivisible principles of agroecology ${ }^{2}$ derived from the Nyéléni Declaration to underlie any solutions coming out of the Summit. However, for the powerful states and corporate actors that have continuously promoted market-driven solutions to reproduce and expand their power in food systems, agroecology represents a clear threat. In 2018, then US Ambassador to the Rome-based agencies of the United Nations, Kip Tom, expressed outrage that the FAO should even consider agroecology, which he described as 'an explicit rejection of the very idea of progress'. ${ }^{3}$

As support for agroecology gained momentum, the Committee on World Food Security began a two-year-long negotiation process over an expert report and policy recommendations that countries can adopt to support agroecology. The name of the report 'Agroecological and other Innovative Approaches for Sustainable Agriculture and Food Systems that Enhance Food Security and Nutrition' (HLPE 2019) was itself a product of compromise that reflects the strategic approach of selective incorporation that the United

\footnotetext{
${ }^{2}$ http://www.ipes-food.org/_img/upload/files/sfsENhq.pdf accessed 30 September 2021.

${ }^{3}$ https://www.usda.gov/sites/default/files/documents/Kip-Tom.docx accessed 1 October 2021.
} 
States and other powerful agro-exporting states mobilized to restrain the radical challenge of agroecology (Montenegro de Wit and Iles this issue). Agroecology was to be considered only alongside other tools for sustainable intensification, thus pushing agroecology onto a highly uneven institutional and political economy terrain that favours the status quo.

\section{How Agroecology is being Coopted: The 'All the Tools in the Toolbox' Claims of Nature-positive Production}

Prominent Summit participants argued that we need 'all the tools in the toolbox' (e.g. that we need both genetic engineering and agroecology, coexisting) (UNFSS 2021b). However, some tools tend to destroy the ability to use other tools, and some tools are completely inappropriate to the task at hand. Moreover, the 'tools' metaphor doesn't work well for food systems: it implies that problems can be solved mechanistically, rather than holistically. This engineering approach ignores not only relationships between tools but a full set of forces 'outside the toolbox' that shape how any tool within it can possibly function. These include political economy (e.g., patent rights, trade liberalization, and other structures in which tools are embedded); path-dependency (e.g., historical lock-ins of certain types of science, technology, and industry in agricultural development); and entanglement (e.g., the interconnectivity of all social-ecological relations) (HLPE 2020). In addition, the toolbox metaphor evades governments' obligations to protect, respect, and fulfill human rights, both nationally and extraterritorially. In particular, it obscures how corporate solutions are seldom compatible with the right to food, because they are based on making profits from agricultural commodities, not the aims of socially and environmentally just food systems, rights to self-determination and development, and redressing human rights violations.

Despite embracing 'food systems' (von Braun et al. 2021), the UNFSS operated with this mechanistic toolbox mentality. But solutions will not materialize by throwing different, often antagonistic, approaches together and calling them nature-positive. Agroecology is not a tool: it is a science, practice, and movement to transform mindsets, eliminate power imbalances, and integrate principles of wellbeing and dignity into interactions between countries, territories, peoples, and the living world.

\section{Overview of the Issue}

This issue begins with a set of three Up Front pieces to help contextualize the UN Food Systems Summit in the history of global food governance. Reminding us that food is 'at the heart of whatever humanity gets up to', McKeon reviews the history of governance in global food systems, identifying critical questions that need to be asked if the agency of rights-holders is to be strengthened and multilateral governance is to be democratized. McMichael explains how this history of weakening multilateralism reflects deepening public-private partnerships, as seen in the "unholy alliance' between the UN and the World Economic Forum. By comparing the UNFSS to previous global food summits, Canfield, Duncan, and Claeys examine how the UNFSS is reshaping food systems governance. They analyze how competing actor networks are struggling to reconfigure the frameworks through which authority and legitimacy are evaluated in the Summit and beyond.

The issue then moves to explore important themes that define, deepen, and clarify the stakes of the UNFSS organization and its scope. Clapp, Noyes, and Grant discuss how the Summit has effectively reinforced the concentration of power in the global food system by being 'strategically silent' on the problem of corporate power, endorsing technology and innovation-based solutions that benefit large agrifood companies, and giving companies a priority seat at the decision-making table. Such technologies and innovations, Montenegro de Wit and Iles argue, form part of a wider strategy to mobilize science to achieve epistemic legitimacy and expand material networks of authority and expertise. In the case of the UNFSS, this has included 'green' evolutions of Green Revolution science and making appeals to inclusivity —of people of color, women, youth, smallholders, and more. One effect of the confusion of inclusions, Fakhri makes evident, is that the Summit obscured a critical dimension of the global food system: international trade policy. He reflects on the World Trade Organization's influence on agricultural trade and proposes a new trade agenda based on a new international food agreement that supports territorial markets and the fundamental right to food. Another critical dimension the Summit has obscured, Coutinho and co-authors say, is the health and ecological impacts of ultraprocessed food products. Using examples from across Latin America, they highlight existing, effective regulatory and governance measures that can be used to reduce corporate control over those products-but were not included in the set of UNFSS 'solutions.'

Pivoting to sketch the contours of a prefigurative future, Guttal asks: What kind of governance is needed for food systems transformation? Guttal argues that in the face of corporate multi-stakeholderism permeating governance structures, the CFS must serve as a space for catalyzing and strengthening public interest-oriented food systems governance grounded in the human rights framework. In order to confront the expansion of stakeholder capitalism, multilateralism itself needs to be democratized with the full participation of rights holders. These priorities are also embraced by Dorado and colleagues who, focusing on legal 
frameworks of corporate accountability, highlight important regulatory elements such as duty of care and prevention of harm, international cooperation between states, and rules to prevent corporate capture of governance spaces. In the end, they argue, a strong, strategic, and sustainable corporate accountability mechanism 'must serve the people's mission and not the profit motive'. From holding corporations accountable to imagining a world without private property altogether, Kuljay et al. call for a decommodification of food through visions and practices aligned with the 'commons'. Commons, they suggest, are an essential part of liberating enclosed food systems that currently thrive on hunger, environmental degradation and inequity. This enclosure, for Van Dyck and Arora, has always been linked to heteropatriarchy and coloniality. They offer a refusal of modern industrial agriculture as 'an act of radical care', moving away from extractive and objectifying technologies promoted by the Summit and towards care for the Earth through diverse agroecologies. In an interview, Nettie Wiebe further elaborates this approach, discussing how to overcome the difficulty of imagining alternatives and the reassurance of the unknown.

In the spirit of scholar-activism, contributions throughout this Special Issue entangle theory and practice, featuring views from academia alongside and in collaboration with civil society experts. The final section of this issue roots these perspectives in specific geographies and communities. From country-level cases to continent-wide perspectives, we hear from the people and organizations already working to transform food systems in Africa, Asia, Europe, North America, and Latin America. For example, GraddyLovelace and Naylor share how the 'Disparity to Parity' project in the US is reviving principles of parity and supply management policy to end the regime of cheap food and support farmers of color in re-territorialized supply chains. From the Brazilian Collective Action on Real Food, Recine and colleagues identify more than 260 examples of pandemic responses in Brazil-showing how the types of policy processes the UNFSS envisioned cannot recognize effective, local, territorial responses to crises like COVID19. Van der Ploeg describes how the UNFSS 'went largely neglected' in Europe, Zhang explores the silenced disputes in Chinese UNFSS Dialogues and analyzes tensions within China's approach to global food systems, and McKeon contextualizes the vibrant African social movement/civil society movements who, in 2021, developed a common position to 'reclaim Africa's food sovereignty and transform industrial food systems'.

\section{Conclusions}

As the articles in this collection make clear, while slim evidence exists for the investor-oriented solutions the UNFSS advanced, solutions rooted in small-scale producer and
Indigenous practices and worldviews have fed societies sustainably for millennia. Scientists can and should be working to support subaltern agroecological knowledge rather than marginalizing its power. While intense involvement by the Gates Foundation and the World Economic Forum presaged a global governance system that will deepen the concentration of agroindustrial power and sideline multilateral structures of accountability, existing frameworks can be revived and reimagined.

As always, resistances have as many lessons as hegemonic maneuvers themselves. In 2019-2021, grassroots counter-mobilizations and protests convened by farmers, Indigenous communities, academics, and peasant-led organizations worldwide showed an animating force that the Summit's power grabs could not contain (Ackermann et al. this issue; Jonas this issue). The organization of the UNFSS unified the food sovereignty movement in opposition to the corporate and philanthropic networks that dominated the Summit, facilitating new connections and igniting a renewed sense of urgency. As the articles in this issue illustrate, organizations united regionally, continentally, and globally to challenge the UNFSS and all that it represents. The UNFSS and its aftermath cannot be allowed to further marginalize people who are producing most of the world's food, who hold unrivaled expertise about agroecology in practice, and yet who suffer most from violations and abuses of their human rights. To achieve the SDGs (and liberatory horizons beyond what the SDGs envisage), countries and institutions must actively support and fund food system transformations grounded in agroecology principles, within the framework of food sovereignty, as affirmed by the Nyéléni Declaration of the International Forum for Agroecology and the CFS High Level Panel of Experts. ${ }^{4}$ Together, agroecology and food sovereignty provide an evidence-based roadmap for rights-based, sustainable, and equitable change, and we offer this collection as part of an ongoing dialogue to manifest that future.

\section{References}

Anderson, Molly. 2015. The role of knowledge in building food security resilience across food system domains. Journal of Environmental Studies and Sciences 5 (4): 543-559. https://doi.org/10. 1007/s13412-015-0311-3.

Bezner Kerr, Rachel, Sidney Madsen, Moritz Stüber, Jeffrey Liebert, Stephanie Enloe, Noelle Borghino, Phoebe Parros, Daniel Munyao Mutyambai, Marie Prudhon, and Alexander Wezel. 2021. Can agroecology improve food security and nutrition? A review. Global food security 29: 100540. https://doi.org/10.1016/j.gfs. 2021.100540

\footnotetext{
${ }^{4}$ http://www.ipes-food.org/_img/upload/files/sfsENhq.pdf accessed 30 September 2021.
} 
Canfield, Matthew, Molly Anderson, and Philip McMichael. 2021. UN food systems summit 2021: Dismantling democracy and resetting corporate control of food systems. Frontiers in Sustainable Food Systems (open Access). https://doi.org/10.3389/fsufs.2021.661552.

Carletto, Calogero, Alberto Zezza, and Raka Banerjee. 2013. Towards better measurement of household food security: Harmonizing indicators and the role of household survey. Global Food Security 2 (1): 30-40. https://doi.org/10.1016/j.gfs.2012.11.006.

Chandrasekaran, Kirtana, Shalmali Guttal, Madhuresh Kumar, Laura Langner, and Mary Ann Manahan. 2021. Exposing corporate captures of the UNFSS through multistakeholderism. Food Systems 4 People (Liaison Group of the People's Autonomous Response to the UN Food Systems Summit). https://www.foodsystems4people. org/wp-content/uploads/2021/09/UNFSSreport2021.pdf

Clapp, Jennifer. 2018. Mega-mergers on the menu: Corporate concentration and the politics of sustainability in the global food system. Global Environmental Politics 18 (2): 12-33. https://doi.org/10. 1162/glep_a_00454.

Fairbairn, Madeleine. 2020. Fields of Gold: Financing the Global Land Rush. Ithaca: Cornell University Press.

FAO. 2014. Sustainable food systems: Concept and framework. Rome: Food and Agriculture Organization of the United Nations. http:// www.fao.org/3/ca2079en/CA2079EN.pdf.

FAO. 2018. The 10 elements of agroecology: Guiding the transition to sustainable food and agricultural systems. Rome: Food and Agriculture Organization of the United Nations. http://www.fao.org/3/ i9037en/i9037en.pdf.

Francis, C., G. Lieblein, S. Gliessman, T.A. Breland, N. Creamer, R. Harwood, L. Salomonsson, et al. 2003. Agroecology: The Ecology of Food Systems. Journal of Sustainable Agriculture 22 (3): 99-118. https://doi.org/10.1300/J064v22n03_10.

Herforth, Anna, and Jody Harris. 2014. Understanding and Applying Primary Pathways and Principles. Improving nutrition through agriculture. Brief \#1. USAID/Strengthening Partnerships, Results, and Innovations in Nutrition Globally (SPRING) Project. https://www. spring-nutrition.org/publications/briefs/understanding-and-apply ing-primary-pathways-and-principles.

Herrero, Mario, Philip Thornton, Brendan Power, Jessica R. Bogard, Roseline Remans, Steffen Fritz, James S. Gerber, Gerald Nelson, Linda See, Katharina Waha, Reg A. Watson, Paul C. West, Leah H. Samberg, Jeannette van de Steeg, Eloise Stephenson, Mark van Wijk, and Petr Havlík. 2017. Farming and the geography of nutrient production for human use: a transdisciplinary analysis. Lancet Planet Health 1: e33-42. https://doi.org/10.1016/S2542-5196(17) 30007-4.

HLPE. 2019. Agroecological and other innovative approaches for sustainable agriculture and food systems that enhance food security and nutrition. A report by the High Level Panel of Experts on Food Security and Nutrition of the Committee on World Food Security, Rome. http://www.fao.org/3/ca5602en/ca5602en.pdf.

HLPE. 2020. Food security and nutrition: Building a global narrative towards 2030. A report by the High Level Panel of Experts on Food Security and Nutrition of the Committee on World Food Security, Rome. http://www.fao.org/3/ca9731en/ca9731en.pdf.

Kremen, Claire, and Albie Miles. 2012. Ecosystem Services in Biologically Diversified Versus Conventional Farming Systems: Benefits, Externalities, and Trade-Offs. Ecology and Society 17 (4): 40. https://doi.org/10.5751/ES-05035-170440.

Loos, Jacqueline, David Abson, Jahi Chappell, Jan Hanspach, Friederike Mikulcak, Muriel Tichit, and Joern Fischer. 2014. Putting meaning back into "sustainable intensification". Frontiers in Ecology and the Environment 12 (6): 356-361. https://doi.org/10.1890/130157.

Martínez-Torres, Maria Elena, and Peter Rosset. 2014. Diálogo de Saberes in La Vía Campesina: food sovereignty and agroecology. The Journal of Peasant Studies 41 (6): 979-997. https://doi.org/10. 1080/03066150.2013.872632.
Marya, Rupa, and Raj Patel. 2021. Inflamed: Deep Medicine and the Anatomy of Injustice. New York: Macmillan.

McMichael, Philip. 2009. A food regime genealogy. The Journal of Peasant Studies 36 (1): 139-169. https://doi.org/10.1080/0306615090 2820354.

Mkindi, Abdallah Ramadhani, Anne Maina, Jan Urhahn, Josephine Koch, Lena Bassermann, Mamadou Goïta, Mutinta Nketani, Roman Herre, Stig Tanzmann, Timothy A. Wise, Melissa Gordon, and Rachel Gilbert, R. 2020. False Promises: The Alliance for a Green Revolution in Africa (AGRA). https://www.rosalux.de/en/publication/id/42635.

Newell, Peter, and Olivia Taylor. 2018. Contested landscapes: The global political economy of climate-smart agriculture. The Journal of Peasant Studies 45 (1): 108-129. https://doi.org/10.1080/03066150. 2017.1324426.

Nyéléni. 2007. Declaration of the Forum for Food Sovereignty. https:// nyeleni.org/spip.php?article290

Nyéléni. 2015. Declaration of the International Forum for Agroecology, Nyéléni, Mali Development 58(2-3): 163-168. https://doi.org/10. 1057/s41301-016-0014-4.

Paprocki, Kasia, and Jason Cons. 2014. Life in a shrimp zone: Aqua-and other cultures of Bangladesh's coastal landscape. Journal of Peasant Studies 41 (6): 1109-1130. https://doi.org/10.1080/03066150. 2014.937709

Pengue, Walter, Barbara Gemmill-Herren (World Agroforestry Centre), Bálint Balázs, Enrique Ortega, Ernesto Viglizzo, Francisca Acevedo, Daniel Diaz, Rosa Fernandez, Lucas A. Garibaldi, Mario Giampietro, Andrea Goldberg, Ashok Khosla (Development Alternatives), and Henk Westhoek. 2018. Eco-agri-food systems: Today's realities and tomorrow's challenges. Chapter 3, 57-109 in TEEB for Agriculture \& Food: Scientific and Economic Foundations. Geneva: UN Environment. http://teebweb.org/our-work/agrifood/reports/ scientific-economic-foundations/.

Petersen, Paolo, and Markus Arbenz. 2018. Special issue: Agroecology: A path towards the Sustainable Development Goals. Farming Matters 34(1.1/1.2): 1-47. http://www.cultivatecollective.org/wp-conte nt/uploads/2018/03/Farming_Matters_special_maart_2018_final. pdf.

Pimbert, Michel, Nina I. Moeller, Jasber Singh, and Colin. R. Anderson. 2021. Agroecology. Oxford research encyclopedia of anthropology. 31 Aug. https://doi.org/10.1093/acrefore/9780190854584.013.298.

Sampson, Devon, Marcela Cely-Santos, Barbara Gemmill-Herren, Nicholas Babin, Annelie Bernhart, Rachel Bezner Kerr, Jennifer Blesh, Evan Bowness, Mackenzie Feldman, André Luis Gonçalves, Dana James, Tanya Kerssen, Susanna Klas, Alexander Wezel, and Hannah Wittman. 2021. Food Sovereignty and Rights-Based Approaches Strengthen Food Security and Nutrition Across the Globe: A Systematic Review. Frontiers in Sustainable Food Systems. https://doi.org/10.3389/fsufs.2021.686492.

Siliprandi, Emma. 2021. Transforming Food Systems through Agroecology: Learning from Evidence. UN Food Systems Summit, Science Days Side Event, 6 July.

Smith, Lisa C., and Lawrence Haddad. 2015. Reducing Child Undernutrition: Past Drivers and Priorities for the Post-MDG Era. World Development 68: 180-204. https://doi.org/10.1016/j.worlddev.2014. 11.014 .

Twomey, Hannah, Christina Schiavoni, and Benedict Mongula. 2015. Impacts of large-scale agricultural investments on small-scale farmers in the Southern Highlands of Tanzania: A Right to Food Perspective. https://www.misereor.de/fileadmin/publikationen/study-a-rightto-food-perspective-2015.pdf.

UNEP. 2016. Food systems and natural resources. A report of the working group on food systems of the international resource panel. Nairobi: United Nations Environment Programme.

UNFSS. 2021a. Levers of Change. https://www.un.org/en/food-systemssummit/levers-of-change. 
UNFSS. 2021b. Why the Fight: Getting to grips with missed opportunities and contentious issues in science and innovations for food systems. Session 4 of UNFSS Science Days, 8 July.

Vidal, John. 2021. Farmers and rights groups boycott food summit over big business links. The Guardian, 4 Mar. https://www.theguardian. com/global-development/2021/mar/04/farmers-and-rights-groupsboycott-food-summit-over-big-business-links.

von Braun, Joachim, Kaosar Afsana, Louise O. Fresco and Mohamed Hassan. 2021. Science for Transformation of Food Systems: Opportunities for the UN Food Systems Summit. UN food systems summit paper, revised 2 Aug. https://sc-fss2021.org/wp-content/uploads/ 2021/07/Scientific-Group-Strategic-Paper-Science-for-Transforma tion-of-Food-Systems_August-2.pdf.
Wittman, Hannah. 2009. Reworking the metabolic rift: La Vía Campesina, agrarian citizenship, and food sovereignty. Journal of Peasant Studies 36 (4): 805-826. https://doi.org/10.1080/0306615090 3353991.

World Economic Forum. 2020. Nature Risks Rising: Why the Crisis Engulfing Nature Matters for Business and the Economy. https:// www.weforum.org/reports/nature-risk-rising-why-the-crisis-engul fing-nature-matters-for-business-and-the-economy.

Publisher's Note Springer Nature remains neutral with regard to jurisdictional claims in published maps and institutional affiliations. 